\title{
The potential and limits of EU crisis
} response

\author{
Pernille Rieker and Kristian L. Gjerde
}

\section{Introduction}

Research on the EU as a global actor has been largely dominated by normative or theoretical convictions or agendas. This has resulted in a sizeable literature focusing on how to understand the EU as an actor. The EU has been variously described as a civilian power (Duchêne, 1972), smart power (Nossel, 2004), normative power (Manners, 2002, 2006), cosmopolitan power (Sjursen, 2006), superpower (McCormick, 2007; Moravcsik, 2010) or a small power (Toje, 2011). This chapter takes a different starting point. Through an in-depth study of how EU foreign policy is implemented it aims to enhance our understanding of the functioning of the EU as an international actor. Rather than focusing on the EU's character, resources or how the systemic features of world politics condition its political behaviour, we concentrate on the Union's foreign policy repertoires and how these impacts the implementation of EU's external crisis response. Such a study will also allow us to conclude on whether the Union's approach can be understood as crisis management, crisis resolution or crisis transformation (see Chapter 2, this volume). The empirical focus is on several crises and conflicts of the past decade in what we may refer to as three concentric areas surrounding the EU: the enlargement area (Kosovo/Serbia), the neighbourhood area (Ukraine, Syria, Libya), and the extended neighbourhood (Afghanistan, Iraq, Mali). It is built on the assumption that while the logic of integration will affect the EU's approach in the two first cases, although in different ways, it will do so less or not at all in the extended neighbourhood. 
The analysis draws on different types of sources. First, the discussion is based on a series of case studies undertaken within the framework of the EUNPACK project. Each case study was based on a series of standardised in-depth interviews and surveys undertaken in summer/autumn 2017 and will be referred to throughout this chapter. ${ }^{1}$ Second, we wanted to gain insights into the official EU discourse about these countries/conflict areas. To this end, we 'scraped' more than seventy thousand press releases from the EC and the Council of the European Union. ${ }^{2}$ We posit that this text collection is well suited for providing some quantitative contextualisation of the development of certain aspects of EU attention to various countries and issues. But first, we need to explain the concept of foreign policy repertoire and why it was chosen as a conceptual starting point for the purpose of this study.

\section{The EU foreign policy repertoire in crisis response}

Analyses of foreign policy behaviour have dominated IR theory and scholarship, but analytical tools for systematically exploring continuity and change are still lacking. This study explores these concerns from a new perspective by applying the concept of repertoires of foreign policy. Rather than focusing on actors' foreign policy character, resources and on how the systemic features of world politics condition certain types of political behaviour, we focus on the repertoires through which actors engage with one another. More precisely, we study the EU's foreign policy repertoire in one specific area - crisis response. Foreign policy repertoire is understood here as the sum total of foreign policy instruments by a foreign policy actor at any given point. This means that the analysis of an actor's use of instruments as well as the interaction of those instruments over time should reveal the logic of this actor's use of its repertoire. While such logics are analytical entities, we assume that they will correspond with an actor's self-identity and that all actors tend to develop relatively stable repertoires of power politics (Nexon and Goddard, 2018), composed of a set of instruments and logics that they deploy to enhance their relative influence, varying slightly according to the foreign policy field. 
A close study of the EU's approach to crises indicates a comprehensive approach to crisis (European Commission and High Representative, 2013, 2015; High Representative, 2016) is seen as the Union's self-identity in this area. Such an approach addresses the whole crisis cycle from pre-crisis to post-conflict stabilisation, with a toolbox suitable for dealing with all these aspects, through 'soft' and 'hard' foreign policy tools. This means that conflict management is not in line with the EU's self-identity. Rather, it aims at having an approach more in line with conflict resolution and perhaps also with elements of conflict transformation.

But what we are interested in here is to investigate how well this EU self-identity and its policy objectives match with actual implementation of EU crisis response activities. In other words, is there an intention-implementation gap? Additionally, we examine a possible implementation-perception gap, which would be a mismatch between the EU's perceptions of its crisis response activities and local stakeholders' perceptions.

\section{Self-identity, objectives, institutions and instruments}

Since adopting a 'comprehensive approach' to crisis management in 2013 (European Commission and High Representative, 2013), the EU has spent considerable time and energy on streamlining its approach and improving internal coordination. New and protracted crises - the conflict in Ukraine, the rise of ISIS, the refugee situation in the South - have made improving external crisis response capacities a top priority (Blockmans, 2015). Thus, the EU has revised both the European Security Strategy (ESS) from 2003 and its ENP. The EU's 'Global Strategy', presented to the European Council in June 2016, offers a practical and principled route to conflict prevention, crisis response and peacebuilding, promoting human security through an 'integrated approach'. The meaning of the integrated or comprehensive approach has been expanded beyond the development-security nexus, and now encompasses a commitment to synergistic use of all tools available at all stages of the conflict cycle while paying attention to all levels of EU action - local, national, regional and global (Council of the European Union, 2016; High Representative, 2016). 
Has all this improved the Union's actual capacity to act - or has it simply widened the 'capacity-expectations gap' identified by Christopher Hill (1993)? In the EU's external crisis response, this gap needs to be specified by two important and related elements. First, 'the intention-implementation gap', which relates not only to the capacity to make decisions based on predetermined objectives, responding with one voice and to deploying the necessary resources (central in Hill's contribution) - but also how these responses are implemented on the ground by EU institutions and member states, and how other actors - local and international - enhance or undermine the EU's activities. Second, there is the gap between the implementation of EU policies and approaches, and how these policies and approaches are received and perceived in target countries: 'the implementation-local reception/perceptions gap'. In order for the EU crisis response to be characterised as a type of conflict transformation, however, both gaps need to be plugged.

Rieker and Blockmans (2018) have surveyed the current state of EU crisis response capacity, presenting the EU's comprehensive approach to crisis and its capacities. Focusing mainly on the Union's resources and administrative capacities in this area, they find that the EU's capacity to act remains hampered by limited resources and a less-developed capacity to utilise available knowledge about the conflict at hand to ensure a conflict-sensitive approach.

Building on these insights, we take one step further to study the instruments and tools available to the EU for intervening throughout the crisis cycle, how they are implemented, and how they are perceived by local stakeholders. Such instruments may include diplomatic instruments (like dialogue and mediation) as well as economic instruments such as sanctions, and civil and military missions to enhance security and humanitarian/development aid.

So far, most research has studied EU capacity to handle crises from a top-down or European perspective, with less attention to the actual implementation phase and the implications of the implementation of EU crisis response, including local perceptions of these actions. Regarding its comprehensive or integrated approach, the EU also stresses the importance of 'local ownership' and 'conflict sensitivity'. But less is known about how or to what extent the EU has managed to achieve this. The aim of this article is to help fill this gap. 


\section{Combining qualitative approaches and text mining in the study of EU crisis response}

The EU's objectives for crisis response are based on the Union's self-identity and inspired by the comprehensive approach. How have they been reflected in actual implementation in recent crisis response activities in the immediate, the near and the wider EU neighbourhood? While this issue has been addressed qualitatively through interviews and surveys in the various regions (these data are included in our analysis below), we will here complement it with a quantitative exploration of word usage in EU documents with the aim of highlighting the attention accorded by the EU to different parts of its comprehensive approach or power repertoires in this field. The main aim has been to trace development over time in the different regions. We have conceptualised the EU's comprehensive policy toolbox - the EU's repertoire for crisis response - as divided into three different agendas, which we postulate will be linked to different terminologies: a 'hard security' agenda linked with words such as 'sanctions' and 'border management', a 'soft security' agenda linked with words such as 'civil society' and 'good governance', and an 'integration' agenda linked with words such as 'integration' and 'association agreement' (see Table 3.1). While the first seems to be more in line with a traditional conflict management

Table 3.1 Selected 'category words'

\begin{tabular}{ll}
\hline Category & Selected 'category words'* \\
\hline Hard security & $\begin{array}{l}\text { border management, migration, refugees, security, } \\
\text { stability, crime, trafficking, sanctions } \\
\text { Sofvil society, good governance, rule of law, dialogue, } \\
\text { mediation, humanitarian aid, development aid }\end{array}$ \\
Integration & $\begin{array}{l}\text { integration, enlargement, membership, conditionality, } \\
\text { association agreement }\end{array}$ \\
\hline
\end{tabular}

\footnotetext{
* The following case-insensitive regular expressions were used to identify these categories in the texts: 'border management|migration|refugeelsecurity (?! council)|stabilitylcrimeltraffickinglsanctions', 'civil societylgood governancelrule of lawldemocraldialog|mediation|humanitarian aidldevelopment aid' and 'integrationlenlargement|membershiplconditionalitylassociation agreement'
} 
approach, both the soft security approach and the integration approach are more likely to include elements of conflict resolution and sometimes also conflict transformation.

To explore this, we first downloaded the entire press release archive of the EC (71,061 documents for the period 2000-16), which generally includes press releases and key decisions made by the European Council and the Council of the EU. ${ }^{3}$ The goal was to see how our three categories of words appear together with mentions of the countries under study. As many documents are long and contain a number of different topics, we split these documents into their nearly four million component sentences ${ }^{4}$ and examined how often the words in the three categories - 'category words' - appeared in the same sentences as the countries under study. Table 3.1 shows the words we have chosen to represent each category.

We should here underline that a different selection (and number) of words clearly could have changed the relative size of the categories. Therefore, what we want to explore is the relative trend between the categories over time, not one year or any overall sum taken in isolation. The aim is that Figures 3.1-3.6, which are based on this procedure and presented below, as a complement to the more qualitative case studies based on interviews and fieldwork, can illustrate developments of the EU's agenda in each case over time, as well as the differences in the EU's approach between these cases.

\section{The power of conditionality, competing priorities and gap in expectations}

In the enlargement area, the EU has the overarching ambition of creating stability through a process of integration based on the mechanisms of conditionality. This was long held to be a very efficient strategy, leading to a reunited and peaceful Europe after the end of the Cold War. Enlargement as such has been cited as the EU's most successful security-policy instrument. It could also be referred to as one of the strongest parts of the EU's foreign policy repertoires when dealing with this specific region.

However, although enlargement is seen as a foreign policy tool, enabling the EU to shape its environment according to its values and interests, this has not been a linear process. Since the 'big bang' 
enlargement of 2004, which led to ten new members, followed by Romania and Bulgaria in 2008, the process has slowed down. The combination of economic challenges and a more challenging geopolitical context has brought greater reluctance to further enlargement. However, there is still general agreement concerning the need to include the current Balkan candidate countries as soon as they fulfil the criteria. In 2013 Croatia joined the EU, while Serbia and Montenegro are official candidate countries and have started the negotiations process. According to an action plan issued by the EC in 2018, the ambition is for Serbia and Montenegro to be full members by 2025 (European Commission, 2018). First, however, both countries must improve in rule of law and governance; Serbia must also normalise its diplomatic relations with Kosovo.

How has the integration agenda, or the EU's conditionality tool, worked in the case of Serbia? To what extent has it considered the concerns of Kosovo? Instead of studying the process of enlargement as such, we focus on the actions taken by the EU and its member states to assist both Serbia and Kosovo in the process towards future membership. Here we examine aspects of the 'normalisation dialogue' between Belgrade and Pristina launched in 2013, as well as the implementation, practices, and perceptions on the ground of EULEX. We also enquire into the importance of this agenda with regard to agendas more dominated by either hard or soft security measures without necessarily being an integration agenda.

The key challenge here is that Serbia did not recognise Kosovo when it declared independence in 2008. A decade later, the official line of the Serbian government is that Kosovo remains an integral part of Serbia, despite the establishment of a parallel structure of government functions as well as the existence of various foreign and diplomatic missions with embassy status in Pristina and Belgrade (Bátora et al., 2018). Here the EU has chosen to apply the practice, common in negotiations concerning international crises, of using ambiguous language as a way of achieving a buy-in by both the conflicting parties and gradual progress towards stabilisation of relations (Bátora et al., 2018). In the EU governance literature, this is referred to as 'constructive ambiguity' - a term used in situations when member states or other parties to a negotiation cannot fully agree on an issue - and ambiguously worded agreements may then be interpreted differently in different international 
contexts. The underlying idea is that this might improve the lives of ordinary people and that it reflects the European method - seeking peace through practical cooperation rather than through grand rhetoric about the 'brotherhood of mankind' (Cooper, quoted in Bátora et al., 2018: 13).

A typical example of such a method is the normalisation dialogue between Pristina and Belgrade: the language has remained sufficiently ambiguous to provide leeway for both sides to operate with varying interpretations (Bátora et al., 2018: 12-13). While ambiguity may allow progress on difficult issues, it also has its costs. According to respondents from the embassies in both capitals, the whole concept of dialogue becomes artificial, superficial or too narrow to deliver (Bátora et al., 2018: 13). In fact, conflicting interpretations also led to the derailing of the normalisation process in 2017.

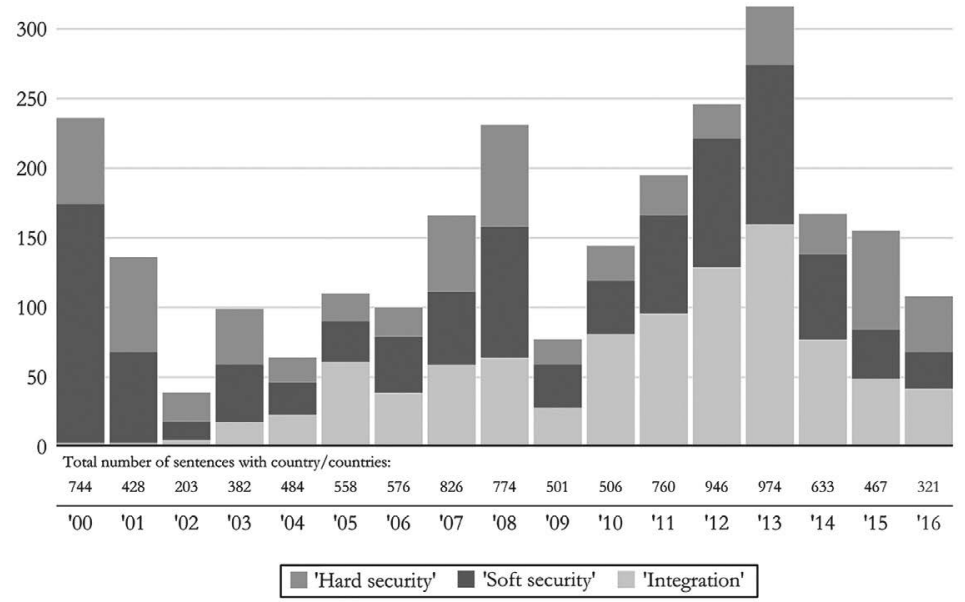

Figure 3.1 How terms reflecting different EU agendas appear in the same sentence as 'Serbia' or 'Kosovo' in our document collection (2000-16). Figures 3.1-3.6 are based on 3,870,946 sentences from 71,434 European Commission and Council of the European Union press releases. The figures show the number of sentences per year that include the country (or countries) and also include words from our 'agenda categories' for each category. All figures made using the ggplot 2 in R package (Wickham, 2016) 
The aim of the EULEX operation was threefold. First and foremost, to provide support to Kosovo's rule of law institutions. Second, to contribute to the Belgrade/Pristina Dialogue by assisting in the implementation of the dialogue agreement in the sphere of the rule of law. Third, to ensure that rule of law services are delivered until the progress of local authorities allows the complete transfer of executive functions to local authorities. Beyond this, the operation contributed to more over-arching objectives: increasing regional stability by preparing Kosovo for EU membership and minimising security threats to Europe emanating from Kosovo.

The EU has had these countries (and the conflict) on its agenda throughout the period. We see that the integration agenda has had a clear presence in our text material, but with a relative decline compared to the security (hard and soft) agendas since 2010.

While progress can be identified, and EULEX is perceived as an important watchdog against human rights abuses, the main challenge has been the conflicting sovereignty claims put forth by Kosovo-Albanians and Kosovo-Serbs. Both sides hold that there is a lack of conflict- or context-sensitivity on the part of the EU: 'while the local institutions are reporting to EULEX, communication only goes in one direction ... the EU is more interested in stabilization than in building democracy within the country' (Bátora et al., 2018: 28). We have not pursued an in-depth analysis of EU attention to these questions in our collection of EU documents, but we do note that a quick search in this text material reveals scant use of concepts like 'conflict / context sensitivity', 'local ownership' or 'local partnership'.

Still, the EU's influence in this region is important, probably more so than that of other international actors. After all, this engagement is closely linked to the EU enlargement agenda. But there are also several obstructing factors. First, there is internal disagreement in the EU concerning the future status of Kosovo. Second, the instrumental use of ambiguity in the normalisation dialogue can promote cooperation - but it also leaves room for multiple interpretations that in turn may undermine trust among the parties. Third, the competing priorities of the EU in the region - stability versus democratisation - also hamper its effectiveness as an actor in the region. Further, poor conflict- and context-sensitivity limit the EU's capacity to deliver on democratisation and stabilisation, so priority 
goes to the latter. Finally, the discrepancy between the initial intentions of the EU and actual implementation of its policies on the ground has led to an expectations gap between the local population and the EU.

\section{Crisis response in the neighbourhood}

Also in its neighbourhood the EU has a special role due to its integration agenda. In parallel to the enlargement in 2004, the EU initiated the ENP to avoid new dividing lines in Europe. This led to aspirations in several post-Soviet states that they might - one day become EU members; and in the South there was optimism concerning possibilities for closer cooperation and association that, in turn, would lead to greater prosperity in the region. While Russia was sceptical about the eastern part of this policy, it was, at the time, more concerned with NATO and its expansion plans. In the South, there were hopes that a relationship hitherto dominated by security concerns would lead to a mutually advantageous partnership. The ENP, further strengthened by the Eastern Partnership $(\mathrm{EaP})$ in the East and the Union for the Mediterranean (UfM) in the South, was seen as an important instrument for (security) community building beyond EU borders, built on the same integration logic as in the enlargement area. While the conditionality mechanism was weaker (in the East) or non-existent (in the South), the objective was still that the EU would be able, by its soft security or power of attraction, to contribute to stability, security and prosperity in the neighbourhood.

The EU's soft power has been considerably weakened from 2011 onwards. After the short-lived 'Arab Spring', the Southern neighbourhood experienced a period of conflicts, wars and failed states. In the Eastern neighbourhood, the crisis in Ukraine and deteriorating relations with Russia have undermined the EU's influence over this region (Rieker, 2016). In fact, these experiences led to a revision of the ENP and the abandonment of the part of EU's self-identity based on the idea that regional integration would automatically lead to security. The revised ENP is less explicit as to possible future membership for the partner countries in the East, and more concerned with providing assistance to these countries in the work of building stronger institutions and good governance: downplaying 
the integration agenda, strengthening the general soft-security agenda.

Also in the South, there have been changes in the EU's approach. In response to the Arab Spring, there came a de-securitisation of the ENP in the South, with a brief period of greater focus on support for democratisation, and to civil society groups. However, maintaining this approach proved difficult as the Arab Spring faded out and was replaced by instability, wars and failed states. A combination of hard and soft security has gradually returned as the top priority for the EU in its relations with this part of the neighbourhood, a trend reconfirmed after the 2015 migration crisis and the series of terrorist attacks in Europe. That is not to say that other concerns have been completely abandoned. There is still the explicit ambition of tackling the root causes of migration and conflict in this region, but the integration agenda has been generally abandoned as a strategy for building security and prosperity. As the ENP has been the main framework for EU engagement in this region, the EU's main security policy tools - the Common Foreign and Security Policy (CFSP) and the CSDP - have played secondary roles. However, more recently, and linked to a changed regional security context, both Ukraine and Libya have experienced the deployment of CSDP missions. This shows that even though the overall trend seems to be greater degree of securitisation, the EU approach is complex and may include different elements.

How can the EU crisis response in one Eastern and one Southern conflict shed light on the EU crisis response repertoire in this area more generally - and how has it changed? Also here the analysis builds on the results of interviews and surveys (Ivashchenko-Stadnik et al., 2018; Loschi et al., 2018), complemented with a text-mining approach.

\section{Crisis response in Ukraine: increasingly security-driven}

The EU's reaction to the crisis in Ukraine, in the aftermath of the annexation of Crimea in March 2014, can be summarised as three groups of measures: first, restrictive measures and sanctions against Russia; second, diplomatic measures of supporting the dialogue within the Normandy Format between France, Germany, Ukraine 
and Russia, combined with the financing of the Organization for Security and Co-operation in Europe (OSCE) Monitoring Mission in Ukraine aimed at monitoring implementation of the Minsk Agreement; and third, the EU missions in Ukraine. Since the crisis started in November 2013, the EU has had two permanent missions in Ukraine: the EU Advisory Mission (EUAM) for Civilian Security Sector Reform, which provides financial, technical and expert support for Ukrainian law enforcement and rule of law institutions and agencies; and SGUA, supporting the effective implementation and application of the EU-Ukraine Association Agreement by the Ukrainian government. The Support Group offers assistance in critical areas of reform and helps coordinate financial assistance to Ukraine on behalf of international financial institutions. In addition, the EU has continued to support the EUBAM in Moldova and Ukraine, operational since 2005.

The attention towards Ukraine (see Figure 3.2) is in line with expectations. Ukraine has been on the EU agenda since 2000 increasingly so after 2004, when the ENP was launched and with the EaP a few years later (2009), and then peaking dramatically in 2014 and 2015 due to the crisis in Ukraine. The integration agenda featured increasingly in EU discourse from 2010, with a peak relative to the other categories in 2013. Since then, the figure seems

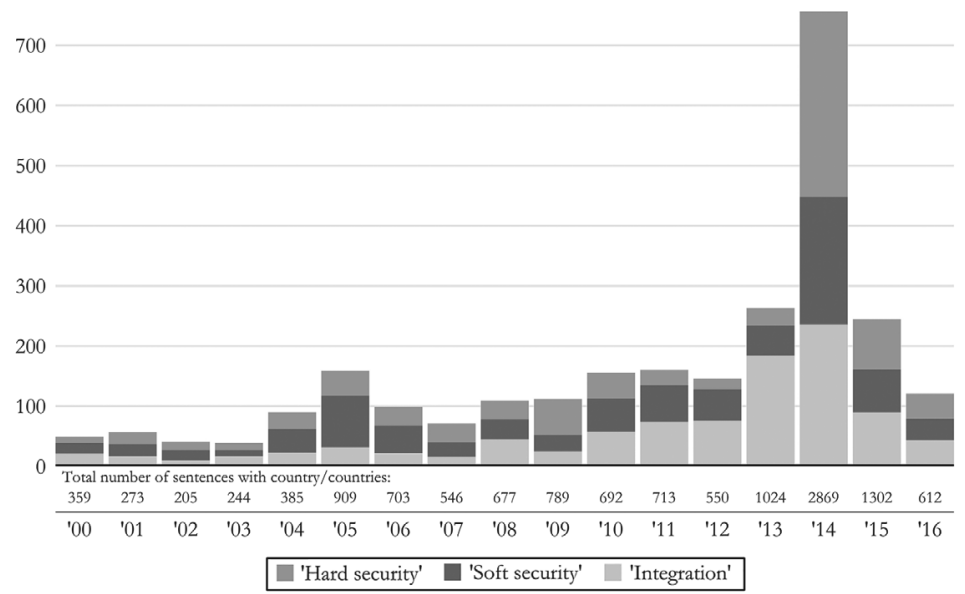

Figure 3.2 Ukraine 2000-16: terms reflecting different EU agendas 
to tentatively support the claim that the EU's approach to Ukraine has become more characterised by a foreign policy agenda based on a combination of soft and hard security agendas, in addition to talk of integration.

The three groups of measures discussed above reflect the move towards support for reforms without mentioning the integration agenda. While this engagement is deemed important in Brussels, EU officials on the ground in Kiev mention three common problems. First, the workflow is too slow, and involves too many bureaucratic procedures. Second, there is a gap between the goals and ambitions of local partners and the EU. Finally, doubts among the local population as to the EU agenda lead to some degree of mistrust (Ivashchenko-Stadnik et al., 2018).

The EUBAM is an exception here, as it is seen largely as a success - probably because it is a more specific mission that provides technical assistance in a clearly defined sector. Local interlocutors indicate that the EU engagement is perceived positively at the general level, but that it is insufficient and has difficulties in adapting rapidly to changing needs. There are fears that the EU's need to balance its relations with Russia will overshadow its engagement in Ukraine in the long run (Ivashchenko-Stadnik et al., 2018).

\section{Crisis response in Libya: limited and security-driven}

While Libya is also part of the ENP on paper, this has never been fully activated. Unsurprisingly, relations between Libya and the EU have remained dominated by a security agenda. The post-Gaddafi period has proven particularly challenging for the $\mathrm{EU}$, as there is no functioning government in Libya to cooperate with. The unstable situation also represents a direct security threat to the EU, as the 2015 migration crisis clearly showed. The EU has responded by giving priority to immediate security threats instead of focusing on more long-term solutions like capacity-building and SSR. The EU has undertaken two CSDP missions in Libya: the naval operation EUNAVFOR MED (Operation Sophia) and EUBAM Libya. Both are directed towards handling the migration challenge. Beyond these operations, the EU has launched a Trust Fund for Africa and Libya, and ECHO is engaged with humanitarian aid (Loschi et al., 2018). 
The initial aim of the EUNAVFOR MED operation was to disrupt the business model of human smuggling and trafficking networks by capturing and destroying the vessels used. While the intentions were good, the result was that the smugglers simply replaced their vessels with cheaper, dangerous rubber boats, leading to increased profits for the smugglers as well as more deaths at sea. There is also the difficulty of stopping the main traffickers and getting them prosecuted. Networks are robust and adapt rapidly. However, there is also reason to believe that there has been insufficient understanding of these networks and how they work, and of the malfunctioning of the Libyan judicial system.

The EUNAVFOR MED mandate has now been adapted and changed, and the overall operation has been more successful - also in the eyes of Libyans. EU vessels have been patrolling the waters outside Libyan cities known to harbour jihadist organisations; since 2017, the EU has expanded its activities to include the fight against oil smuggling, which fed territorial militias, fuelling the war economy and preventing the internationally recognised government from establishing its authority. It has been argued that the inclusion of these tasks has improved the overall coherence and led to greater acceptance of the EU crisis response in Libya (Loschi et al., 2018). But not all EUNAVFOR MED activities have been so successful. Because of the lack of authorisation to operate inside Libyan waters, the training part of the operation was not implemented systematically; this also revealed the lack of knowledge about the competence and the needs of the local agency (Loschi et al., 2018). When it became known that Libyan coastguard officers, trained by the EU, had been responsible for misconduct and abuses of human rights, it was recognised that this part of the operation had failed.

The civilian CSDP mission EUBAM Libya was launched in May 2013, mandated to help the Libyan authorities to develop a concept for integrated border management in Libya. As border management is challenging in a country that lacks a consolidated state apparatus able to control its territory, the EUBAM was seen as an appropriate tool for fostering border management across the country, at least if it could manage to improve coordination with EU member states, like Italy, also engaged in Libya. But EUBAM Libya was also tasked with conducting the preliminary planning of a possible future CSDP 
mission for more comprehensive SSR, aimed at countering irregular migration and the smuggling of migrants. With the mission's mandate changing and broadening, the specificities of Libya's security sector and its lack of governance represented major challenges (Loschi et al., 2018). The EU failed to take these aspects into account - showing how lack of in-depth knowledge about the situation on the ground, and thus the lack of a genuine bottom-up perspective, can hamper operations and prevent success (Loschi et al., 2018: 12-15).

Beyond the CSDP operations, the EU Trust Fund for Africa and Libya was established to provide rapid, flexible, effective response to the migration-related emergency situation. The Fund was directed towards programmes that would manage mixed-migration flows in Libya by expanding space and supporting local socio-economic development. While the intention was precisely to ensure local ownership of rapid-impact stabilisation projects by creating job opportunities, re-structuring local services, and reinforcing education services, this initiative has also been criticised for being too top-down in orientation and for marginalising the role of local stakeholders. In response, the Commission will now ensure that all projects undergo a 'conflict sensitivity assessment' (Loschi et al., 2018: 17).

Despite these recent changes, the EU's approach to the Libya crisis has remained basically unchanged since the 2014 recognition of the security crisis in the country. Moreover, short-term objectives seem to have taken precedence over more strategic long-term objectives. As migration became securitised and framed as an emergency, the EU and its member states have focused increasingly on protecting European interests and not those of the local population. The EU crisis response in Libya has been characterised by a huge gap between intentions and actual implementation, and thus also a gap in expectations.

Attention to Libya has varied over time. Not surprisingly, there was a peak in 2011 (see Figure 3.3). Hard security has been dominant, but is not the only agenda present in the EU discourse: the EU has also been concerned with softer measures. The 'integration' category is also present in our material in certain periods, with a relative peak when the ENP was launched in 2004. Since then, the security agenda in general and hard security in particular has 


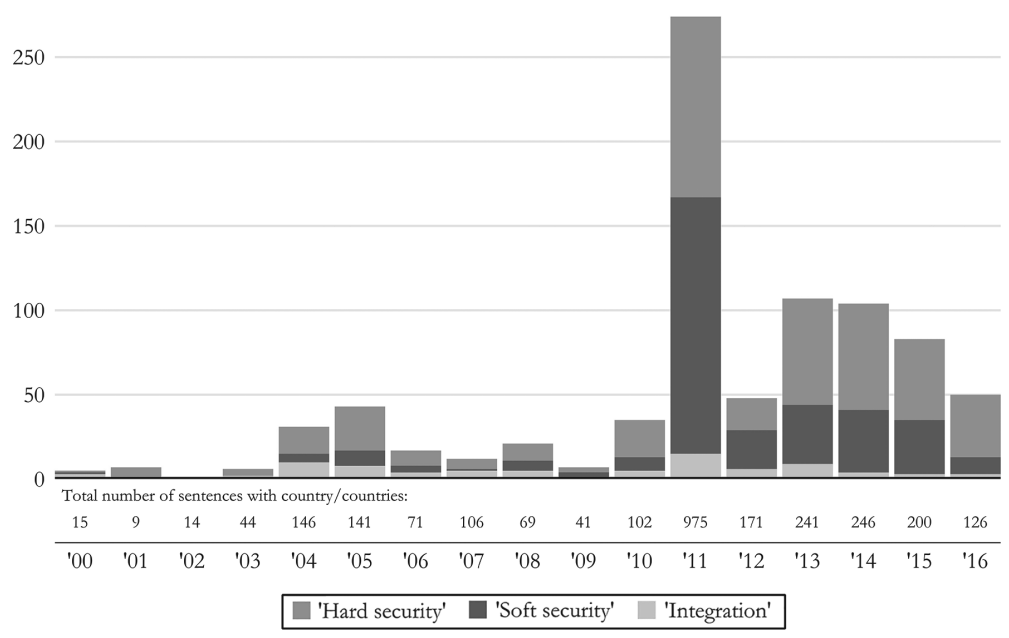

Figure 3.3 Libya 2000-16: terms reflecting different EU agendas

dominated, but the continued focus also on softer measures show also here that a securitisation is not the whole story.

\section{The wider neighbourhood: Afghanistan, Iraq and Mali}

Beyond Europe and its neighbourhood, the EU's approach changes character, and is no longer defined or steered by the logic of integration. Thus, in many ways, EU policy towards more distant countries comes closer to regular foreign policy. But exactly what is it that characterises EU policy in the wider neighbourhood? Is it dominated by a hard or a soft security agenda? To what extent are the concerns of conflict sensitivity and local ownership taken into account? Here we briefly examine the EU's engagement in three countries - Afghanistan, Iraq and Mali - and how it is perceived by local stakeholders (Suroush, 2018; Mohammed, 2018; Bøås et al., 2018).

\section{Crisis response in Afghanistan}

With Afghanistan, the main EU engagement is the EU Police Mission (EUPOL). At the G8 conference in Geneva in April 2002, 
the donor community for Afghanistan decided on a division of labour for establishing and training Afghan security forces. Among the EU member states, the UK was assigned to combatting drugs, Italy to revision of the justice sector and Germany as the lead on police reform. On 23 April 2007, the EU Council decided to establish EUPOL in Afghanistan, intended as a nonexecutive mission, focused on monitoring, mentoring, advising and training (Suroush, 2018). In terms of staff and budget, EUPOL was a minor player in Afghan police reform - at least compared to NATO and the United States - but it provided a 'civilian surge' complementing the US/NATO military deployment. It also had a small but important role in the construction of the new Police Staff College in Kabul, where it was particularly committed to the promotion of policewomen and the inclusion of human rights in Afghan police training. According to local stakeholders, EUPOL had a real but limited impact on the civilian aspects of Afghan police reform.

EUNPACK project surveys in Kabul show that 69 per cent of the respondents had heard about EUPOL and 75 per cent of the staff at ministries and in the police were trained by EUPOL. The gender and the human rights programme emerged as the best-known programme in addition to the establishment of the Police Staff College according to a survey undertaken in Kabul (Suroush, 2018). However, EUPOL has been criticised for failing to apply the SSR model due to security concerns, weak domestic institutions, institutional discord within and between Euro-Atlantic institutions, and lack of commitment to the EUPOL mission (Suroush, 2018: 18). At the local level, Afghan police have expressed discontent with EUPOL's long and complicated decision-making procedures.

Beyond its limited but generally positive impact on the ground, EUPOL was also seen as important by the EU itself: as an opportunity to expand its role as a global actor and also because it would promote the comprehensive approach to post-conflict reconstruction and peacebuilding. While Afghanistan was most frequently discussed in 2001 and 2002, it was accorded considerable attention throughout the period under study (see Figure 3.4). Not surprisingly, security-related words dominate, but, judging by the choice of words used in our data material, the EU seems to have maintained a balance between discussing 'hard' and 'soft' security. 


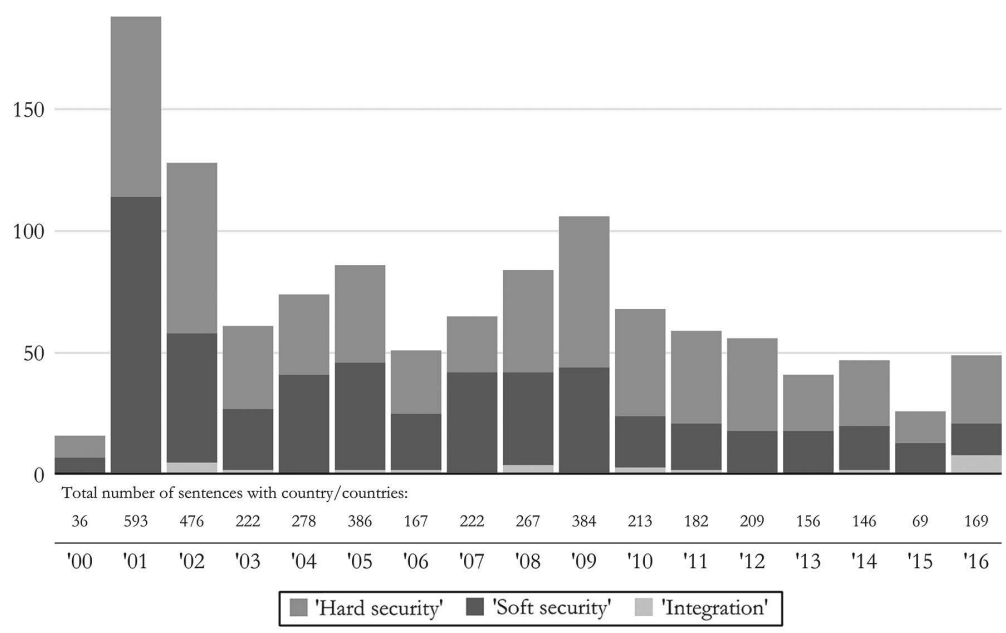

Figure 3.4 Afghanistan 2000-16: terms reflecting different EU agendas

\section{Crisis response in Iraq}

Since the toppling of the regime of Saddam Hussein in March 2003, the EU has come to play an active and supportive role in Iraq. The EU's financial and political footprint remained relatively light in the early years following the invasion in Iraq but increased later in preparation for the two elections, held in January and December 2005, with a training programme for election observers and the dispatch of electoral observers to Baghdad. Later, the EU maximised its engagement when it realised that a failed Iraq would weaken the existing regional order, negatively impacting the interests of many EU member states (Mohammed, 2018). The EU engagement has involved financial support to the post-war reconstruction phase; 2005 saw the launch of the EU Integrated Rule of Law Mission for Iraq. EU-Iraq relations were underpinned by two agreements: a Memo of Understanding on energy cooperation, and a Partnership and Cooperation Agreement. Once the EU established permanent presence in Iraq, it became engaged in providing support for strengthening the state's governance structure in many different areas.

Mention should be made of the EUJUST LEX-Iraq mission, as well as the EU's work on reconstruction, development, and 
humanitarian aid. The former sought to promote closer collaboration among actors throughout the criminal justice system, strengthen the management capacity of officials for the police, judiciary and penitentiary, and improve skills and procedures in criminal investigation with full respect for the rule of law and human rights (Mohammed, 2018).

Our text collection shows that the general attention accorded to Iraq was at its highest in the first half of the period, starting from 2003, which is not surprising. The 'soft security' vocabulary seems to have been relatively more dominant in EU attention towards Iraq in this early period, with 'hard security' being more dominant later (see Figure 3.5). Results from surveys and interviews show that the EU lacks visibility in Iraq and that many people are unaware of its engagement. In particular, they have difficulty distinguishing between the EU's engagement as such and that of individual member states. Humanitarian assistance was best known; less familiar were the EU's efforts in development aid and rule of law.

While Iraqis in general held rather good impressions of the EU, those able to distinguish between the member states as well as local stakeholders who had been working with the EU on the ground claimed that the EU's engagement lacked sustainability and

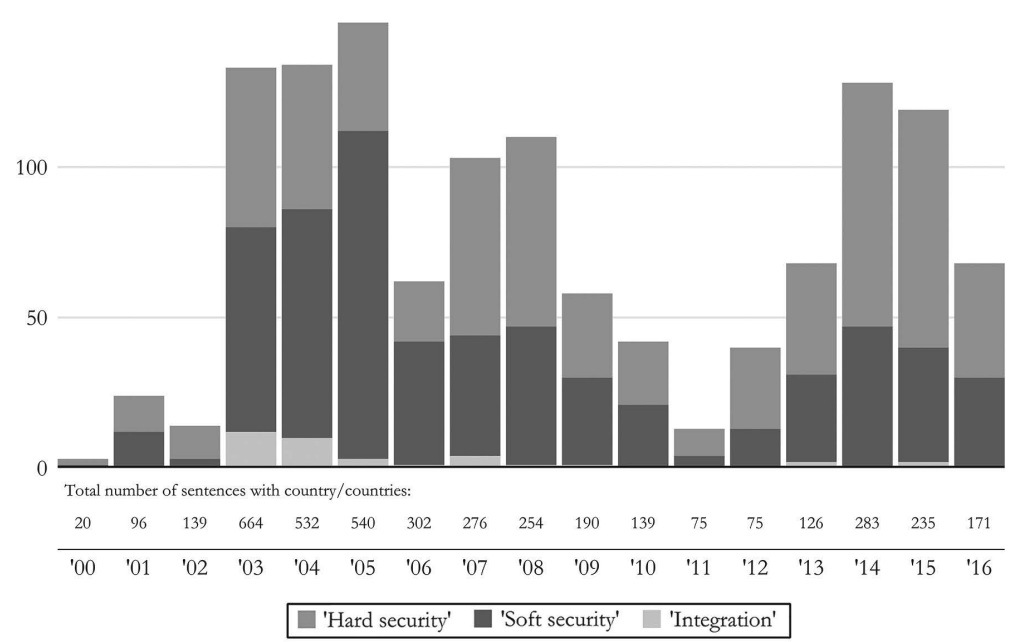

Figure 3.5 Iraq 2000-16: terms reflecting different EU agendas 
continuity; they also expressed doubts about the impact of EU activities. The main reasons highlighted were limited resources and insufficient understanding of the situation on the ground.

\section{Crisis response in Mali}

The EU's concern with fragile states in Sahel is nothing new. This became evident through the EU Strategy for Security and Development in the Sahel (EEAS, 2011). The conflict that erupted in Mali in 2012 pushed the issue higher up the agenda, and the migration crisis in 2014/15 made the Sahel a high-politics concern for Europe. Various actors are involved in Mali: the UN with MINUSMA, France with its Operations Serval and Berkhane, and the deployment of two EU police and military training missions - EUCAP Sahel Mali (2015-) and the European Training Mission (EUTM) to Mali (2013). The EU is also involved in border management through the EU Trust Fund.

However, security in Mali is deteriorating, and the conflict has spread to the centre of the country (Bøås et al., 2018). Both MINUSMA and the French operations have lost much of their initial popularity. So far, the EU has been less affected. However, as many local Malians have problems in understanding what the EU interventions are, and in distinguishing between EU and French actions, their anger and frustration with France may also affect the EU. The French approach is criticised for defining the crisis as caused by foreign terrorist insurgencies, which some see as a convenient excuse for not dealing with the underlying internal causes of conflict and the drivers of violence (Bøås et al., 2018).

Further, it is argued that even though EUTM Mali and EUCAP Sahel Mali were well-intentioned, they ended up producing mixed results on the ground. The main challenge with the EU training mission is that it remains a non-executive mission: it does not participate in combat, nor accompany the Malian armed forces in operational zones. With EUCAP it is the change of mandate that is seen as the key problem. It was established in 2015 with a mandate to support the restoration of state authority in Mali (EUCAP, 2018), but it soon came to concentrate mainly on Mali's counter-terrorism services and support to Malian authorities regarding irregular migration, including trafficking and border control (Bøås et al., 
2018). As the EU sees the 'problem of porous borders' as a key challenge in Mali and in the Sahel more broadly, it is also involved in several other projects with border mandates, as with the new funding tool, EU Emergency Trust Fund (EUTF), which has the mainstreaming of migration management in all EU external action as its core objective. EUTF is not a separate mission, but a fund that operates through other programmes and missions. One of these is the G5 Sahel, where the EU has deployed a designated border expert to support the G5 Permanent Secretariat elaborating a regional border strategy for Mali/Mauritania, for Mali/Niger/Burkina Faso, and for the border between Niger and Chad.

The EU crisis response in Mali is characterised by a clear gap between intentions and implementation. As the stated goal is to contribute to the restoration of state authority in Mali, and this will take time, the EU perspective has gradually become more shortterm and security-driven - in turn, offering limited potential to build legitimate, operational and sustainable police and armed forces.

For Mali, data from our web-scraping exercise show that attention from the EU has increased from virtually zero since 2000, with a peak in 2012-13 (Figure 3.6). Further, the 'hard security' agenda

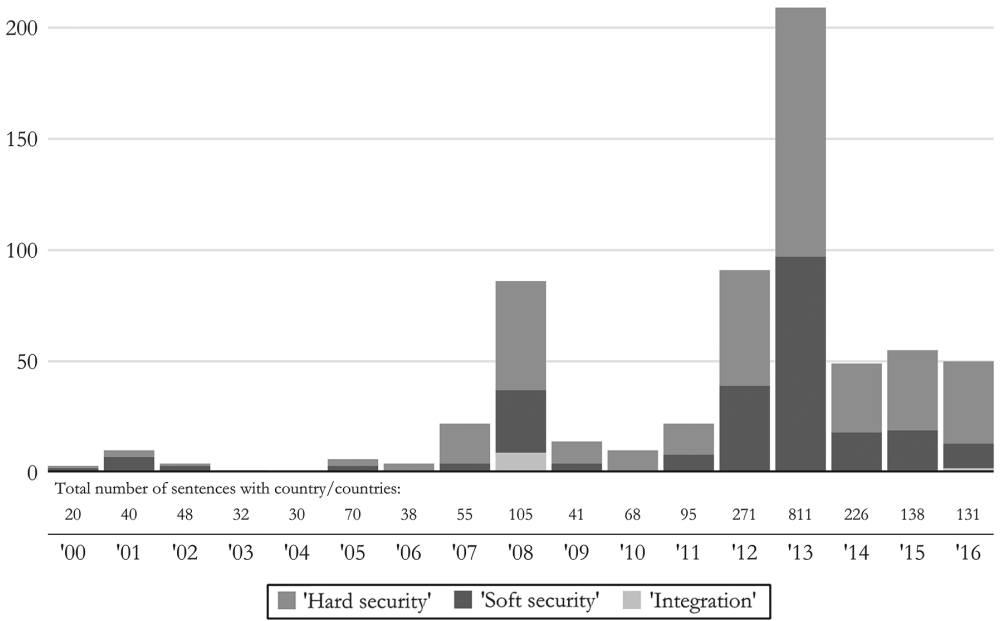

Figure 3.6 Mali 2000-16: terms reflecting different EU agendas 
appears to predominate over the 'soft security' agenda, in line with the EU being seemingly more focused on handling issues like trafficking, terrorism and crime, than on contributing to good governance and democracy-building.

The intention is to leave a 'light footprint' through building ownership with local partners, but in reality, programme design has generally come from policy-makers in Brussels who are worried about terrorism, trafficking and refugees. This lack of conflict sensitivity is clear from Council documents, where the distinctions between the different groups in Mali are blurred. Although the training of the Malian army is appreciated, it is argued that there has been too much focus on short-term technical training. Also, the fact that EUTM personnel train an army at war without being able to monitor trained soldiers in action considerably limits the mission's ability to provide valuable follow-up, and see whether the training actually works. There is a need to improve border control, but it is challenging to stop illegal trafficking while facilitating trade in general. Moreover, the various training programmes proposed are often not relevant for the local context. This lack of context sensitivity may be linked to the huge turnover in EU staff, as personnel never get time to familiarise themselves with the local context (Bøås et al., 2018).

\section{Concluding remarks}

What has this comparative study of the Union's approach to these different crises revealed about the EU's foreign policy repertoire as regards crisis response? How has this repertoire been applied in relation to crises in three concentric areas surrounding the EU: the enlargement area (Kosovo/Serbia), the neighbourhood area (Ukraine, Syria, Libya), and the extended neighbourhood (Afghanistan, Iraq, Mali)? Finally, how have EU missions and activities been perceived locally - is there a match or a mismatch between EU intentions and implementation, and the perceptions of local stakeholders?

The most apparent trend is the shift towards a greater focus on security rather than integration, in the enlargement area and in the neighbourhood area; and an increase in the harder 
security agenda in the region referred to here as the 'extended neighbourhood' - especially in the Mali crisis, which is closest to the EU; but also to some extent in Afghanistan and to a lesser extent in Iraq. Another key finding is the general lack of understanding of the local situation, and poor conflict sensitivity, both of which are likely to limit the impact of EU crisis response. This indicates that the EU has not yet implemented a crisis response approach that can be characterised by Crisis Transformation.

The first trend indicates a certain match between EU intentions and the implementation in the field of crisis response. Here the EU engagement is in line with the main orientation of the 2016 Global Strategy, Shared Vision, Common Action: A Stronger Europe (European Union HR/VP, 2016), which emphasises the need to safeguard the security of European citizens and the EU as such - to be pursued through an approach referred to as 'principled pragmatism'. This represents a deviation from the more normative approach outlined in the 2003 ESS, A Secure Europe in a Better World, where the emphasis was on creating security through processes of Europeanisation and the promotion of European values. Ironically, the EU has now managed to plug the intention-implementation gap - but by adjusting its intentions rather than actual implementation.

Also taking into account the limitations with this line of inquiry that we pointed out above, the analysis of the presence of 'category words' for the countries/conflicts under study also seem to suggest a general trend whereby security - hard or soft - is given more attention relative to an 'integration' vocabulary.

Concerning the match or mismatch between on-the-ground implementation on the one hand and local perceptions of this engagement on the other, interviews and surveys in the various countries show that in all crises where the EU has been engaged, it has been criticised by local populations for not taking into consideration the specificities of the conflict, and thereby also largely failing to provide local ownership or show conflict sensitivity. A quick search in our database of EU documents also showed that concepts like conflict- or context-sensitivity or local partnership and local ownership were never mentioned, or very rarely.

In conclusion, while the intention-implementation gap has been closed by adjusting intentions, the gap between implementation and local perceptions is still far from being closed. While the emphasis 
on security may be understandable, given the current geopolitical context, it marks a move away from the EU's self-identity of having a comprehensive repertoire in the area of crisis response. That being said, the continuing lack of conflict sensitivity is probably the most obvious limit of the EU repertoire in crisis response and shows the continued persistence of a top-down, Brussels-centred approach and an approach that is limited to the management and potentially resolution of crisis rather than crisis transformation.

\section{Notes}

1 For more information, take a look at www.eunpack.eu

2 For details, see below.

3 The Commission press release database (http://europa.eu/rapid/) does not appear to include the documents summarising the meetings of the various configurations of the Council of the European Union after the first half of 2013. For the period 2013-16, we manually added 313 such documents, to increase the consistency of the data over time.

4 Using the spaCy (Honnibal and Johnson, 2015, see https://spacy.io/) Python library. The premise is not that the recognition of sentence boundaries in the texts is flawless, but that it is good enough for our purposes.

\section{References}

Bátora, J., K.M. Osland, F.M. Kvamme and S. Stojanovic (2017) 'Public perceptions of the EU's role in crisis management in North Mitrovica', Policy Brief D.5.3, EUNPACK project.

Bátora, J., M. Navrátil, K.M. Osland and M. Peter (2018) 'The EU and international actors in Kosovo: Competing institutional logics, constructive ambiguity and competing priorities', EUNPACK Working Paper D.5.2, EUNPACK project.

Blockmans, S. (2015) 'The 2015 ENP Review: A policy in suspended animation', CEPS Commentary, 1 December, www.ceps.eu/system/files/ SB\%20ENP\%20Review\%20CEPS\%20Commentary.pdf (accessed 2 October 2020).

Bøås, M., A.W. Cissé, A. Diallo, F. Kvamme and E. Stambøl (2018) ‘The EU, security sector reform and border management in Mali', EUNPACK Working Paper D.7.4, EUNPACK project. 
Council of the European Union (2016) 'Taking forward the EU's Comprehensive Approach to external conflict and crises', Action Plan 2016-17, Joint Staff Working Document SWD(2016) 254 final (19 July) (Brussels: European Commission).

Duchêne, F. (1972) 'Europe's role in world peace', in R. Mayne (ed.), Europe Tomorrow (London: Fontana), 32-47.

EEAS (2011) 'Strategy for security and development in the Sahel' (Brussels: EEAS), http://eeas.europa.eu/archives/docs/africa/docs/sahel_strategy_ en.pdf (accessed 3 September 2020).

EUCAP (2018) 'EUCAP Sahel Mali mandate', https://eucap-sahel-mali.eu/ about_en.html (accessed 1 June 2021).

European Commission (2018) 'A credible enlargement perspective for and enhanced EU engagement with the Western Balkans', Communication from the Commission to the European Parliament, the Council, the European Economic and Social Committee and the Committee of the Regions, COM(2018) 65 final (Strasbourg: European Commission).

European Commission and High Representative (2013) 'The EU's Comprehensive Approach to external conflicts and crises', Joint Communication to the European Parliament and the Council, JOIN (2013) 30 final (Brussels: European Commission and High Representative of the Union for Foreign Affairs and Security Policy).

European Commission and High Representative (2015) 'Taking forward the EU's Comprehensive Approach to external conflict and crises, Action Plan 2015', Joint Staff Working Document SWD(2015) 85 final (Brussels: European Commission).

European Union HR/VP (2016) Shared Vision, Common Action: A Stronger Europe. A Global Strategy for the European Union's Foreign and Security Policy (Brussels: EU).

Hill, C. (1993) 'The capability-expectations gap, or conceptualizing Europe's international role', Journal of Common Market Studies, 31(3): 305-328.

Honnibal, M. and M. Johnson (2015) 'An improved non-monotonic transition system for dependency parsing', Proceedings of the 2015 Conference on Empirical Methods in Natural Language Processing (Lisbon: Association for Computational Linguistics), 1373-1378.

Ivashchenko-Stadnik, K., R. Petrov, P. Rieker and A. Russo (2018) 'Implementation of the EU's crisis response in Ukraine', EUNPACK Working Paper D.6.3, EUNPACK project.

Loschi, C., L. Raineri and F. Strazzari (2018) 'The implementation of EU crisis response in Libya: Bridging theory and practice', EUNPACK Working Paper D.6.2, EUNPACK project. 
Manners, I. (2002) 'Normative power Europe: A contradiction in terms?', JCMS: Journal of Common Market Studies, 40(2): 235-258.

Manners, I. (2006) 'Normative power Europe reconsidered: Beyond the crossroads', Journal of European Public Policy, 13(2): 182-199.

McCormick, J. (2007) The European Superpower (New York: Palgrave Macmillan).

Mohammed, K. (2018) 'The EU crisis response in Iraq: Awareness, local perception and reception', EUNPACK Working Paper D.7.2, EUNPACK project.

Moravcsik, A. (2010) 'Europe, the second super power', Current History (March): 91-98.

Nexon, D.H. and S.E. Goddard (2018) 'Repertoires of power politics', Conference Paper, International Studies Association Annual Convention, San Francisco, 4-7 February.

Nossel, S. (2004) 'Smart power: Reclaiming liberal internationalism', Foreign Affairs (March/April).

Rieker, P. (ed.) (2016) External Governance as Security Community Building: The Limits and Potential of the European Neighbourhood Policy (London: Palgrave Macmillan).

Rieker, P. and S. Blockmans (2018) 'Towards a conflict sensitive EU crisis response?', paper prepared for the panel, 'The EU, crisis response, and the intentions-implementation gap', International Studies Association Annual Convention, San Francisco, 4-7 February.

Sjursen, H. (2006) 'What kind of power?', Journal of European Public Policy, 13(2): 169-181.

Suroush, Q. (2018) 'Assessing EUPOL impact on Afghan police reform (2007-2016)', EUNPACK Working Paper D.7.3, EUNPACK project.

Toje, A. (2011) 'The European Union as a small power', JCMS: Journal of Common Market Studies, 49(1): 43-60.

Wickham, H. (2016) ggplot2: Elegant Graphics for Data Analysis, 2nd edn (Cham: Springer). 